\title{
SOME PHYSIOLOGICAL EFFECTS OF MOMORDICA CHARANTLA AND TRIGONELLA FOENUM-GRAECUM EXTRACTS IN DIABETIC RAT AS COMPARED WITH CIDOPHAGE
}

\author{
Wehalsh, F. E.; Abo-Ghanema, I. I.* and Rasha, Mohamed Saleh \\ Physalotagy Department. Faculity of Veterinary Medicine. Mansoura Untveraity \\ -Physkology Department, Faculty of Veterinary Mediche. Alexandria Univerglty-Damnhur branch
}

\begin{abstract}
Ethanalic extract of Momordica charantia (BM) and Thgoretla foenum-graecum[(7) were used to investigate their antidiabetic activity in streptozotocin (5TZ) induced diabetic albino rais. BM and TG were given to the STZ induced dlabetic rats at the concentration of $500 \mathrm{~m} / \mathrm{kg}, 50 \mathrm{mg} / \mathrm{kg}$ body weight respectively in dufferent groups, orally once a day for 4 weeks. Cidophage is aiso given to another grouy to support the results at the concentration of $500 \mathrm{mg} / \mathrm{kg}$ body weight oraily orice a day for 4 weeks. The results reveled that oral adininistratton of plant extracts significantly reduced givcose tevels in the following order: cidophage (1.08 fold), bitter melon (1.17 fold). and fenugreek (1.33 fold, as compared with healthy contral rats. Insulin secretion was stmulated after 4 weeks of beatment with cidophage 10.87 fold $)$, bitter melort 10.86 foldl. and Fenugreek f0.79 foldl as compared with non-dlabetic healthy control one. Lewels of the liver en: zymes AST and ALT were normalked with bitter melon and ferwugneek treatment in a simllar degree as with chtophaye, suggesting an improvement in ther functlons. Creatinine teuels were normallzed in all treated groups. Regarding to lipid profle. there were decreases in liver cholesteral, troglycerides, and lol in diabetic rats after treatment with extracts. On the other hand. HDL levels were increased in the following order bitter melon, cktophage, and fenugreek respectively. Serum niltric axtde and malonalde. hyde levels were reduced in all treated groups. Levels of the anti-ondant GSH were arcreased in all treated groups. Euar's Blue extratrasation test (as a measure of peripheral capllary permeabilly) signfficantly increased in the skin of dicabetic animals. This effect was restored by ethanolic extracts of bitter melon, and fentugreek re spectively. The diabetic group also showed delayed unound healing compared with the treated diabetic group as ineasured by histopathologlcal observator. Applying the ex perimertial extracts acrelerated the rate of unound closure, indicating the beneficial role of the butter melon and fenugreek extracts in the healing process of the dlabelic anound. Histopathological examination of pancreas from diabetic rats showed stirunken islets and their shape were destroyed with infutration of lymphocytes compared to contral group. In the ntean time. animals treated with the experimental extracts showed bigger and comparable islets to that of normal rats. The enlougernent of islets in diabetic ani-
\end{abstract}


Wehaish, $\boldsymbol{F}, \mathbf{E}$; et al...

mals post treatment was higher in bitter melon-treated group followed by fenugreekgroup.

It was concluded that the ethanolic extracts of bitter meton, and fenugreek exhibit promising and safe antt-diabetic activily esprecially on peripheral circutation as mantfested by decreased peripheral capllary permeablity and accelerated uound healing In an animal model of tupe $1 \mathrm{DM}$. Hence, it nay be pursued for thetr cllnical usefulness in the management of diabetes melttus and other associated complications.

Fey words: Diabettc rats, Peripheral circulation, natural plants.

\section{INTRODUCTION}

Diabetes mellitus (DM) is the syndroune of disturbed energy homeostasis. causcd by an abnomal metabolisin of cartrohydrates, proteins and fats. It Is the most common endacrtne-metabolic disorder worldwide (Powers, 2008). The mosi devastating compllcation of DM is vascular complications Including poor wound healing as a result of peripheral vascular permeability dysfunction (Nadas et al., 2009).

Untll now, the research for new antidlabet$k c$ agents represents a challenge to medical prolessions. For many ycars. maruy herbs and plant products have been shown to have hypoglycemic action. among them are feaugreek, and bitter melon. Fenugreek seed (Trifonella foenum-graecum L.) has been slown to reduce glucose levels in type 2 diabetes and may help do so in type 1 (Insulin dependent) dlabetes (Haxanen al., 2007). Momordlca charantia, also is referred to as bitter melon or bitter gourd, is commonly known as vegetable insulin and has bcen used as a traditional ant-clabietic remedy for trany years (Virdl et al., 2003).

Most of the studles that handled these plants were focused on thetr action on hyper- glycemla and/or insulln metabollsm. However. their effects on peripheral circulation and vascular pathology are stlll unclear. Thus the present study was planned to investugate the effects of these plant extracts on vascular permcability in pertpheral clrculation in addltion to thelr effects on nitric oxyde and axddatrue stress in rats with streptozolocin-induced diabetes.

\section{MATERLAL AND METHODS}

\section{2-1: Experimental andmaln :}

Aduit male albino rats weighing 200 to $220 \mathrm{gm}$ were housed in Physiology Department. Faculty of Veterinary medictine, Mansoura Unlversity. Animals were left for one week to acclimatize the place. Rats were kept in cages in a rate of stx rats per cages and were provided with standard diet and water ad-libltum.

\section{2-2: gtroptozotocln-Induced dabetlc an-} tmal modol;

Induction of diabetes was done using the diabtogenic compound streptozotoctn (STZ) (Elsner et a1., 2000). In our study a single dose of $50 \mathrm{mg} / \mathrm{kg}$ or streptozotocin STZ (Sigma Chenscal Corapany St. Lou/s, Missouri) in $0.1 \mathrm{M}$ citrate buffer $6.1 \mathrm{M}$ Citric actd. $0.1 \mathrm{M}$ Trisodium citrate, $\mathrm{pH}$ is 4.5) was administrat- 
ed Intrapretoncally in a total volume of 1.0 inl. After 3 dlays of STZ injection, blood samples were laken from lup of the tail and hyperglyeemla was conflmed by measuring blood glueose levels directly using glueometer fone toueh technology, Roche group UKM. Antmals showing lasting blood glucose higher than $250 \mathrm{lng} / \mathrm{dl}$ were eonsidered dlabetic and were included in the study. Treatments were given dally by stomach tube after 3 days of inducthon of dlabeles and conllnued for 4 weeks. Anjonals were divided into the lollowing groups (6 rats each):

Group (1): tncludes healthy rats served as normal control.

Group (2): includes rats received STZ only and served as dlabetle control.

Group (3); dlabetic rats recelved daily dose of $500 \mathrm{mg} / \mathrm{kg}$ BW of cidophage.

Group (4): diabetic rals recelved dally dose of fenugreek ethanollc extract (50 $\mathrm{mg} / \mathrm{kg} \mathrm{BW}$ ).

Group (5): dlabetic rats recelved dally dose of bitter melon ethanolic extracl $1500 \mathrm{mg} / \mathrm{kg}$ BW).

\section{2-3: Preparation of the ethanalic ex* tracts:}

Fruits of bitter melon were cultivated in the Faculty of Agriculture-Mansoura Unlversity. Fcinugreek was purchased from local commcrclal sources of Mansoura elty. A tolal of $250 \mathrm{~g}$ of elther ground dry fenugreek sceds, or ground bitter melou werc extracted with $1.0 \mathrm{~L}$ of $95 \%$ ethanol for 5 days. The extraet was evaporated to dryness in a roLavapor (Ajr Blow Equlpinent. Chonnal. India) at $40-50^{\circ} \mathrm{C}$ under roduced pressure. A semtsolkd material was obtalned $(15-20 \mathrm{~g})$. It was stored at $0-4^{\circ} \mathrm{C}$ unul usod. When necded. the residual extraet was suspended in distlled water and used tn the study in the previously stated concentratious (Senanayake et al.. 2004).

\section{2-4: Blood nampling}

Arter 4 weeks post STZ injection, foud was withdrawn for 12 hours. The lasung animals were sacrificed and blood samples were collected into clean centrifuge tube. The blood samples were allowed to coagulate and centrifuged at 3000 rprn for 20 minutes to geparate blood serum. Separated serum was stored at $-20^{\circ} \mathrm{C}$ for subsequent blochemical analyses.

\section{2-6: Blochemtcal Analyaos:}

Serum Glucose was determined according to (Trinder, 1969). Serum levels of alanine amlnotranłferase (ALT) and aspartate aminotransferase (AST) wcre detenolned accordlng to method of Reltman and Frankel, (1967). Detcrmlnation of serum creatinine was donc according to Larsen (1972). Serum cholesterol. HDL cholesterol levels were determined according to Nalto (1984). Determinatkon of serum triglyceride was done according to Buccolo $G$ and David $H$ (1979). Serum LDLcholesterol was determined according to Frfedewald et al., (1972). Determination of serum reduced glutathlone (GSH: was done according to Beutler et al., (1063). Determunation of nitre: oxdde (NO) was done according to method of Gtustarinl et al., (2004). Serum llpld peroxdde (Malondlaldehyde) was determined according to Tataukd et al., (1097). Serum Insulln was detcrmined by automated Insulin Iminumoassay using Elecsys autoanalyzer (Roctre Dlagnostics Mannkelm. Gernany), according to the manufacturer's Instruc* tlong (Sapin et a.. 2001). 
Wehatsh, F. E.; et al...

2-6: Measuremento of Mlcrovapcular Permeablilty (Evang Blue Aosay):

Evans blue, (a tetrasodlum dlazo salt) extravasation test was used to measure vascular permeabillty (Verel, 1958), Evans blue (20 ung $/ \mathrm{kg}$ ) was injected in the caudal veln. where It rapldly binds to plasma albumin. Alter 10 munutes, animals were kdlled and samples from dorsal skin were taken for determination of the extravasated Evans blue. Half of skin sample was dried at $60^{\circ} \mathrm{C}$ for 24 hours. and a dry/wet weight ratlo was ealculated to avofd underestimation of $\mathrm{EB}$ dye concentration due to local edema. The other halr was placed in a formarnlde solution ( $4 \mathrm{~mL} / \mathrm{g}$ wet tissue) for 24 h lor dye extraction. The extracted amount of EB dye was determined by spectrophotometry at $620 \mathrm{~nm}$ using a 96 well microplate photometer. The concentration of $\mathrm{EB}$ was then calculated from a standard curve and expressed as $\mu \mathrm{gg}$ of $\mathrm{EB}$ per $\mathrm{g}$ of dry tissues (ChsIrir et al. 1998).

\section{2-7: Wound creatlon:}

Wounds were ereated after three days of induction of dabetes. Under anesthesia, the baek of all the rats were shaved and skın wounds were prepared $(2.5 \mathrm{~cm}$ dlameter and a depth of about $0.1 \mathrm{~mm}$ ) (Whltby and Fergucon, 1991; Most et al., 1996). Anlmals were sacrificed at days 3 and 28 after wound erea tjon. Skln samples were exelsed, fixed in 10\% formalln. Sildes were stalned with hematoxylin and eosin (H\&E) for light mkeroscopy evaluation.

\section{2-8: Fitutopathologleal analyale:}

Pancreas and skin yound tusues from each rat were fixed overnight in to\% buffered fornalin colution and embedded in paramin.
Sections (4 $2 \mathrm{~m})$ were prepared and stained with $H \& E$.

\section{2-9: Btatlatienl analyols:}

Data were analyzed by analysts of variance using the general liner model procedure of SAS (SAS lnstitute. 2004).

\section{RESULTS}

\section{3-1: Serum Glucose Levele :}

Serum glucose levels were signiflcantly inereased in diabetic group when compared with the control one. After four weeks of treatment, glucose levels were signiflcantly decreased in all treated groups with cidophage. bitter melon, [enugreek respeetively (Table 1).

\section{3-2: Serum tnaulin lepeln :}

Serum Insulln levels were signiffeantly decreased in dlabetic group as compared to normal one. All treatments Inereases Insulln levcls slgnlficantly; however, thls increase was higher in bitter melon than eldophage and Fenugreek respextuvely (Table I).

\section{3-3: Liver Enzymea:}

After Four weeks of treatment, both AST and ALT levels were signifleantly nommallzed by the treatment with cidophage, bltter melon. and fenugreek respectively (Tables 1).

\section{3-4: 8erum kevol of Creatinino:}

There were stgntilcant Increases in creatinure levels in drabetic group. Four weeks post treatment, creatinlne levels were reduced in all treated groups (Tabie 1).

\section{3-5: Serum Lapld Profle :}

There were significant tncreases in levels of serum cholesterol. triglycerdes, LDL, and sig- 
nulcant decreasc in HDL levels in diabetic group indicating a disrupung Upids metabotfsm. Aftcr four weeks of treatment, eholcsteral. triglycerldcs, and LDL levels were reduced signticantly in the following order bltter medon, cldophage, and tenugreek respectuvely (Table 2). HDL levels were signiffcantly increased in the order bitter melon, cidophage. and renugreek respectively (Table 2 ).

\section{3-6: Froe radlcals and antloxddants:}

Therc were signilncant increased in levels of sorum nltrie oxlde (NO) and malonaldehyde (MDA) and slgnificant decreascd in reduced glutalione (GSH) levels in diabetic group. A[ter four wceks of treatment, serum nitric oxIde and malonaldehyde levels were signiflcantby redueed in all treated groups (Table. 3). Reduced glutathione levels were increased in all treated groups (Tabte 3).

\section{7: Level of vascular prermeablilty :}

There was a signiflcant increased in vaseular permeablity in diabetuc group as comparcd to normal onc. After four weeks or treatment. Evans blue (EB) dye levels were stgnificanly reduced in the following chtophage, bitter melon and renugreek, respectively (Fig. I).

\section{3-8: Histopathology of the pancreas}

Histolugical finding of normat pancreas (Fig. 2A) showed predominant exocrine pancreatlc thssuc eamposcd of aclni with draining ductules. Moreover, each tslet was separated from the actnl by retlcular membrane and was arranged in anastomosing cellular plate or cards of cells, cells, D cells and F cells, Fancreatic islets of diabetic rats (Fig. 2P) revealed sigmificant archllectural disarray, which sometimes extended into the surrounding exoerine thssue. Islets were damaged, shrunken in stze and infiltration of very few lymphocytes was observed.

In diabetle treated rats (Fig. $2 \mathrm{C}$ and $2 \mathrm{D}$ ): the endocrtne component of pancreas (Istets of Langerhans) retalned normal histology ofth a scattered nodules within the substanees of thc exocrine pancreas and exhiblted no patholuglcal changes (No signs of panereatius).

\section{3-9. Higtopathological rosalts of eturs wound :}

a. Three daye post wound creation:

In normal control group. the created wound was showed flling of the wound gap with blood clot (Abrin. neutrophils and blood plateicts), The Inflammatory cells (mainly neuIrophilg) tricreased by tumc to peak at three days. Later on, macrophages started to replace the neutrophils ( $\mathrm{Fig}$. $3 \mathrm{~A}$. The inflammatowy response covered with thick crust (necrotic infiammatory ecllo, tissue and tactertal colony). The re-epthellallzation was seen slarting from the wound edges. In diabetic control group, the created wound was showed less inflammatory cells as compared with non diabetic one (Fig. 3A). The wound of dlabetic rat treated with Fenugreek showed increases in number of Inflammatory cells as compared with dlabetic group (Fig. 3C). The wound healIng of diabetic rat treated with Butter melon showed inflammatory phase with inflammatory cells more than which was observcd in group 2 and 3 but stul less than the control (Fig. 3D)

b. Twenty-eight days after wound creatlon The created wound in the cuntral froup 
showed mature epldermls with epldermal papllat besides mature fibrous tissues with few numbers of inflammatory cello (FIg, 4A). In the diabetic group, the created wound was showed complcte reepithellaization of the dermis with absence of eptdermal papllae. Crust remnant was still observed. The dermis showed less mature granulation tissue innitrated with gumerous inllammatory cells (Fig. 4B). The wound of diabetic sal treated with Fenugreek was showed complete recplthelialization with apparenty normal eptdermal thickness. Gramulation tossue innltratcd with macrophages was secn in dermis (Fig 4C). The wound healing of dlabetic rat treated with Bitter melon showed same picture of previous group except presenee of epldermal papillae, more collagen libers and less inflammatory cells (Flg. 4D),

\section{DISCUSSTON}

Dlabetes mellitus complucatlons Include cardiovascular disease, chronic renal falture. retinal damage, and poor wound healing. Poor lhealing of wounds, partucularly of the feet. can lead to gangrene, possibly requiring amputation (Cobenas and Splezirn, 2003). In diabetes. hyperglycemia often leads to various pertpheral vascular complications (Amind and Parvaresh, 2009). The present investigatjon showed that administration of ethanolic ex tract of bitter melon (BM) in a dose of (500 $\mathrm{mg} / \mathrm{kg} \mathrm{BW}$ ) normaltzed fastung bloot glueosc levels to 1.17 fold changes of non-dlabetic healthy control rats in comparison to 6.22 folds increascs in STz dabetic untreated rats. Fenugreek was reduced the blood glucose levcls $(1.33$ fold $)$ as compared with non-diabetic healthy control rats.
Normally, blood glucose levels are tightly controlled by insultn, a hormone produced by the pancreas. Insuln lawers the blood glucose level when It elevated after meals. In the present investigation, serum Insulin levels were slgnificantly reduced with Induction of diabetes. Treatment with cidophage and bitter meton were slgntficantly enharaed insultn hormone secretion after 4 weeks of treatment. Whereas, Fenugreek was normalized the effects of STZ Injection on Insulin secretion to lesser extent. These data conntrms with theoretical mechanism of bltter melon in normallz. Ing biood glucose levels by entrancting Irusulin secretion (Nerurkar ot al., 2008; Shlh et al., 2009].

The llver is an important insullndependent Ussue, which plays a plwotal role in glucose and lipld homeostasis and is severely affected during djabetes (Dol at al., 2007; Inous et al., 2008). In the present study, Induction of drabetes by STZ in rats lnduced elevaled liver enzymes ALT and AST. These results are in accordance with previously studies reported that the Increase in ALT actuvitues in diabetes were usually due to hepatoccllular damage and was usually aceompanied by an increase in AST activites (Pepato ot al., 1999). Moreovcr, the AST and ALT actuvity has been used as an indicator of llver functions (Ezekwe and Martin, 1980). In the present study after four weeks of treatment. both AST and ALT levels were nommallzed in bitter melon and foriugreek in a simular degree as with cldophage. The decrease in AST and ALT In treated groups towands near nomal levels is an evidence of the prevention of cellular and tussue damage under dabetic condttions. These results are in agreement with 
prewous study whleh reported that bitter melon signifieantly improves liver funetions (Ba. drin et al., 2006].

Liver also partieipates in the uptake of oxidation and metabollc conversion of ratty acids, the synthesis of eholesterol and phosphoIjplds and the secretion of specinc classes of serum lipoproteins. In dlabetes. Iatty actds are increasingly taken $n p$ by the llver and, after esterfication with glycerol phosphate, they are deposited as triglyeerides. As a result. dlabetle llver steatosis develops (Martocchia et al., 2008). In the present investigation, there was an Incrcase in serum cholesterol level of diabette rats wilch in agreement with prevous studles reporting that the Imbalance in uipid proflle observed in DM could be due to Increascd cholesterogenesls (Krong of al., 1981). The present study showed a decrease In liver eholesteral, triglyeerides, and LDL in diabetic rats after treatment with bitter meton and renugreek treatments in a slmilar degree as with didophage treatment. This reduction may be attributed to Increased clearance and decrcased production of the major transporters of endogenousiy syntheyzed cholesterol and triglycerides. Whereas, HDL Icvels were increased in the order from bitter melon, cldophage. and fermgreek respectively. These data are in agreement with other studies reporting the abillty of bltter melon (Chaturvedl et al., 2004) and Fenugreek (Sharma at al., 1990) in modulatung lipld proflle.

Diabetes mellitus affects the kidney and is the learting cause of dubetie nephropathy (lwataks et al., 1998). Several studies have shown the presence of llpid depasits in the ludney of diabetic human may play an inplor- tant role In the pathogenesls of diabetie kidney disease (Guijarro et al., 1995). Levels of seinum ereatinine refleet the kidney lunetions Wafar et al., 2005). It has been reported that the rate of glomerular eell (podocyte) apoptosis is increasod in rats with streptozotocininduced diabetes mellitus (Menint et al., 2007). In agreement with thls stady, in the present irvestigation, there was a signifeant increase in levels of serum creatinine after STZ Injcction. Four weeks post-treatment. creatinine levels were reduced in all treated groups. These results are in agreement with Hamden al. (2010) who found fenugreek could reduce creatinine in alloxan-Induced d1abetes. Moreover, our results agree with other researchers who found bitter melon reduces serum creatunine and kldney weight and $1 \mathrm{~m}$. proves glomular filtration (shetty et al.r 2006).

In dlabetes, there is an inerease the pro. duction of reactive oxygen species (ROS) (Kakkar et al., 1998: Bhatta al., 2003). ROS could be effectively eliminated by several intracellular and extracellular antl-oxidatlve systems (Lapobina et al., 2006). When the generation of ROS exceeds anti-oxidant defense mechanisms, these unstable molecules interant with biologic macromolecules such as IIplds, protelns and DNA and lead to structural changes as well as lunctional abnomnallties. It has been reported that increased oxldative damage Imeasured as levels of malondlaldehyde (MDA) or its product thiobarbiturle reactive substanees [TBARS)I and lowered antloxdant defenses (measured as activitjes of antioxtdant enzymes, sitamin $E$ or C) were the underlying mechanlsm of dlabetes complleatlons. An Increase in TBARS leve! 
promotes DNA and proteln alterations Includtng changes in the enxyme activities implicated In lipld metabollsm and free radicals scavenging process (Kakkar ot al., 1985; Watanabe et a1., 1909). SImllarty, Increased levels of nititc oxlde end products have been reported in patients of DM (Bhatia ot al., 2003). Marked production of NO leads to pathologlcal changes in various physkologlcal systerns (CodgsantI and Surukd, 2000; Perreault and Marette, 2001) leading to perfpheral vascular diseases (Maejimn et al.. 2001: Behrendt and Ganz. 2002). Glutathione, the primary endogenous antioxddant, has a multilaceted role in antloxtdant defense and it is a direct scavenger of free radicals as well as a Co-substrate for peroxide detoxification by glutathione pcroxdases (Whterboura. 1095). In agreement with these studies, we found that MDA and NO were Increased in comparison to control group. Moreover, in diabetic group reduced glutathlone was decreased Indlcating a disruption in the balance of the redox system. Four weeks posttreatment, serum nitre oxdde and malonaldehyde levels were reduced in all treated groups bitter melon, cldophagc, and fenugreek.

In diabetes. several mechanisms partictpates in the pathologic inanges observed in endothelial ceils. Including hypernsulinemia. Increased oxddative stress, and inactivation of NO (Jowhua at al., 2008; de Jager et al., 2006; Picchl ot al., 2006). Early in the course of dlabetes. Intracellular hypergycema causes abnormalties in blood flow and Increased pertpheral vascular permeability (Brausewetter of al., 2001; Gordon, 2004). The Increase lo captllary perncablity is a sign for the microvascular dystunction at the artertolar and capllary level resulting in both structural as well as functional changes espectally in peripheral organs, accounting for a group of disorders called peripheral vascular disease (PVD) In which obstruction of large arterles in the armo and lege may occur (Abaci et al., 1999). In the present investigation. vascular permeablity to albumli was as sessed at the end of the experiment using Evans' Blue dye (Huthen ot al., 1005). We found a slgniffcant increase of Evans blue (EB) leakage primartly in skin of STZ-dlabetlc animals, this flnding is th agreement with previous studies (Vibortl, 1983; Lawson et al., 2005). Four weeks post-treatment, dye extravasation levels were reduced in the following order cldophage, bittermelon, and renugreek respectively. However. cldophage and bittermelon appears to exert higher but gimslar effects in reducing caplllary permeabllity than fenugreek. Other studies also reported the ability of some other plant products in nornalzing capllary permeabluty (Makajtma et al., 2001).

PVD is a common and aevere compllcation of diabetes that is characterzed by damage to or blockange in the blood vessels distant from heart.. In the diabetic root the thickened basernent membrane is belteved to impair migration of leukocytes as well as blood flow through the capllarles. These ehanges. and an impaired neurogenle vasodilatory response, results in an inablity to achlcue a normal hyperemic response needed after loot Injury and incrcase the risk of tnfection (Bild ef al. 1088). These Andings account for the 15-fold tncrease in risk for lower extremity amputation seen in diabetic patients (Finzur et al., 2008). It has been reported previously 
that cutaneous wounding results in a decrease in antloxtdant status as a result of the production of ROS. One research study reported that any diabetic uJcer that lasts for more than 4 wecks Is usually an Indication of worse outcome and may lead to amputation (Jefficoste et al., 200s). In the present study, the dlabetlc group showed delayed wound healing compared with the treated dlabetic group as measured by histological observa." thon. These findings are In agrcement with carlicr studlcs (hawanabe et al., 2007: giu et al. 2006). The administration of Bitter unelon and Fenugreck extract was found to accclerate wound closure. Moreoycr, we found that the treatcd group with renugreek and BItter melon showod inrreased granulation tsssue as compared the nori-treatcd group that may be due to stumulation epithclial cell prokferation and migration to wound area. This was evddent in the hlstologleal studles indicating the beneficlal role of the bitter melon and fenugreek extraets on accelerating wound healing. These observations are in agreement with other studies reporting that if the bistopathology of the wound shows rapld eplthelial development. it may be considered as a postthe Slgn (Serarslan ot al. 2007).

We further Investigated the effects of the different extracts on the pancreas histology. Diabetes in the prcsent study was dndueed by
Injection of STZ that targets pancreatic (3-cells via the glucose transporter (GLUT2) and causes alkylation of DNA, thereby damaging the paricreatic $\beta$-cells (Elaner of al.. 2000; sxkudelakl. 2001). In agreement with these studles. the histopathologleal examination of pancreatic sections from diabetic group showed shruaken 1slets and thetr shape were destroyed with infltration of lymphocytes. In contrast, treated animals showed more islets and they become comparable to normal rat islets, although there were Individwal differences. Enlargement of islets in diabetic animais post treatment was higher in bitler melon-treated group than fenugreek treated group. These data are in agreement with previous studled showed abillty of bitter melon (Teoh et al., 2009) and fenugreek (Chovaller, 2000) in accelerating wound healling.

\section{CONCLUSTONS}

It was concluded that the ethanolle extracts of bitter melon, and fenugreek exhlbit promisiru and safe antl-diabettc acturity especlally on pertpheral cheulation as manificsted by decreased vascular captllary permeability and accelerated wound healing $1 \pi$ an anlmal model of type-1 DM. Heriee. It may be pur* sued for their clinical usefuloess in the managcment of dlabetes mellitus and other assoclated complications. 
Wehaish, F. E.; et al...

Table (1): Effect of differeat treatments on studied biochemical parameters.

\begin{tabular}{|c|c|c|c|c|c|}
\hline Group & $\begin{array}{l}\text { Glucose } \\
\text { mg/dl }\end{array}$ & $\begin{array}{l}\text { Insulin } \\
\text { uU/mL }\end{array}$ & $\begin{array}{l}\text { AST } \\
\mathbf{I U} / \mathbf{L}\end{array}$ & $\begin{array}{l}\text { ALT } \\
\text { IU/L }\end{array}$ & $\begin{array}{c}\text { Crestinine } \\
\mathrm{mg} / \mathrm{dL}\end{array}$ \\
\hline Normal contral & $98.33 \pm 4.84^{d}$ & $5.29 \pm 0.005^{\circ}$ & $30.66 \pm 1.20^{\circ}$ & $8.33 \pm 1.86^{\circ}$ & $0.54 \pm 0.08^{\mathrm{c}}$ \\
\hline Diabetic control & $611.33 \pm 7.26^{\circ}$ & $2.11 \pm 0.06^{\mathrm{e}}$ & $81 \pm 2.08^{\circ}$ & $38.33 \pm 2.60^{\circ}$ & $1.56 \pm 0.09^{\prime}$ \\
\hline Cldophage & $106.33 \pm 4.80^{d}$ & $4.61 \pm 0.16^{6}$ & $3 I \pm 2.08^{d}$ & $12 \pm 0.58^{\mathrm{dk}}$ & $0.61 \pm 0.01^{c}$ \\
\hline Fenugreek & $130.33 \pm 6.48^{\circ}$ & $4.18 \pm 0.04^{c}$ & $35.33 \pm 0.33^{\text {ed }}$ & $13.66 \pm 0.67^{\mathrm{ed}}$ & $0.6 \pm 0.06^{\circ}$ \\
\hline Bitter melon & $115 \pm 7.09^{\mathrm{ed}}$ & $4.50 \pm 0.17^{b}$ & $32 \pm 3.6 \mathrm{~J}^{\mathrm{d}}$ & $13 \pm 1.15^{\mathrm{ed}}$ & $0.57 \pm 0.03^{\circ}$ \\
\hline LSD & 19.82 & 0.36 & 7.015 & 4.289 & 0.1666 \\
\hline
\end{tabular}

Valueg are mema $\pm \$$.E, Values with different jetters io each columb are significantly difrerewt at $(P<0.05)$.

Table 2: Effect of different treatments on lipid profile parameters.

\begin{tabular}{|c|c|c|c|c|}
\hline Group & $\begin{array}{c}\text { Cholesterol } \\
\text { mg/dl }\end{array}$ & $\begin{array}{c}\text { Triglycerides } \\
\text { mg/dL }\end{array}$ & $\begin{array}{l}\mathrm{LDL} \\
\mathrm{mg} / \mathrm{dL}\end{array}$ & $\begin{array}{l}\text { HDL } \\
m g / d L\end{array}$ \\
\hline Nonwal control & $114.33 \pm 4.37^{b}$ & $119 \pm 2.08$ & $48.53 \pm 4.65^{\circ}$ & $42 \pm 0.90^{\prime}$ \\
\hline Diabetic control & $204.67 \pm 5.49^{\circ}$ & $245.67 \pm 6.399^{\circ}$ & $141.51 \pm 6.23^{n}$ & $14.03 \pm 2.04^{d}$ \\
\hline Cidophage & $97.33 \pm 4.91^{\text {ed }}$ & $111 \pm 5.29^{b c}$ & $34.61 \pm 4.46^{\mathrm{c}}$ & $40.530 .63^{\circ b}$ \\
\hline Fenugreek & $106 \pm 4.04^{\text {bed }}$ & $118+4.16^{b}$ & $45.10 \pm 4.68^{\mathrm{edd}}$ & $37.3 \pm 1.48^{b x}$ \\
\hline Bitter melon & $93.67 \pm 2.85^{d}$ & $105 \pm 2.65^{\circ}$ & $31.18 \pm 3.28^{\mathrm{d}}$ & $41.48 \pm 1.02^{\circ}$ \\
\hline LSD & 13.183 & 12.535 & 14.35 & 3.835 \\
\hline
\end{tabular}

Valyes are mean \pm S.C. Values with diltereat letters lo each coluan are sigaticantly different at $(\mathrm{f}<0,05)$. 
Wehaish, F. E.; it al...

Table (3): Effect of different treatrnents on oxidants and anti-oxidant parameters.

\begin{tabular}{|c|c|c|c|}
\hline Group & $\begin{array}{c}\text { NO } \\
\mathrm{umol} / \mathrm{L}\end{array}$ & $\begin{array}{l}\text { MDA } \\
\mathbf{n g} / \mathbf{m L}\end{array}$ & $\begin{array}{c}\text { GSH } \\
\mathrm{mmol} / \mathrm{L}\end{array}$ \\
\hline Normal control & $1.26 \pm 0.10^{\circ}$ & $1.21 \pm 0.13^{b}$ & $34.59 \pm 1.23^{\circ}$ \\
\hline Diabetic contral & $25.43+2.39^{\prime \prime}$ & $2.7 \pm 0.09^{\prime}$ & $17.03 \pm 0.6^{5}$ \\
\hline Cidophage & $4.64 \pm 0.18^{b}$ & $1.36 \pm 0.03^{\circ}$ & $34,24 \pm 0.56^{\circ}$ \\
\hline Fenugreek & $3.06 \pm 0.09^{\mathrm{ke}}$ & $1.35 \pm 0.02^{b}$ & $33.36 \pm 0.02^{1 t}$ \\
\hline Bitter melon & $3.94=0.20^{\mathrm{bx}}$ & $1.36 \pm 0.06^{6}$ & $33.65 \pm 1.10^{\mathrm{at}}$ \\
\hline LSD & 2.776 & 0.205 & 3.486 \\
\hline
\end{tabular}

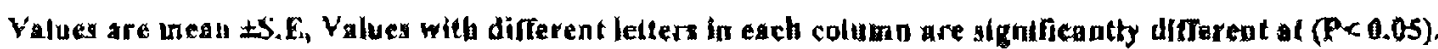

Table 4: Fold change of the studied biochemical parameters after the different treatments as compared to normal control values.

\begin{tabular}{|l|c|c|c|c|}
\hline & STZ & Cidophage & Bitter melon & Fenugreek \\
\hline Gilucose & 6.22 & 1.08 & 1.17 & 1.33 \\
\hline Insulin & 0.40 & 0.87 & 0.86 & 0.79 \\
\hline AST & 2.64 & 101 & 1.04 & 1.15 \\
\hline ALT & 4.60 & 1.44 & 1.56 & 1.64 \\
\hline Cregtinine & 2.91 & 1.13 & 1.06 & 1.11 \\
\hline Cholesterol & 1.79 & 0.85 & 0.82 & 0.93 \\
\hline Triglycerides & 2.06 & 0.93 & 0.88 & 0.99 \\
\hline HDL & 0.33 & 0.97 & 0.99 & 0.89 \\
\hline LDL & 2.92 & 0.71 & 0.64 & 0.93 \\
\hline GSH & 0.49 & 0.99 & 0.97 & 0.96 \\
\hline NO & 20.18 & 2.10 & 2.33 & 2.43 \\
\hline Permeability & 9.60 & 1.75 & 1.94 & 2.66 \\
\hline
\end{tabular}


Wehaish, F. E.; et al...

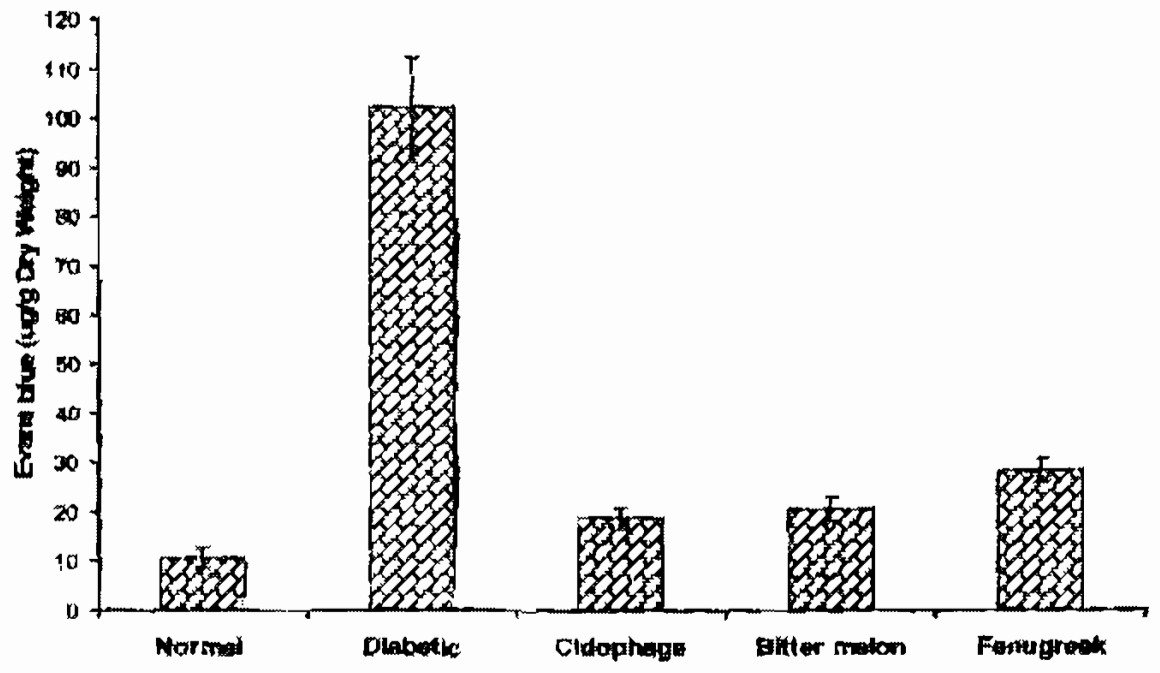

FLyure 1: Vascular permeability as Indicated with Evans Blue assay in skin.

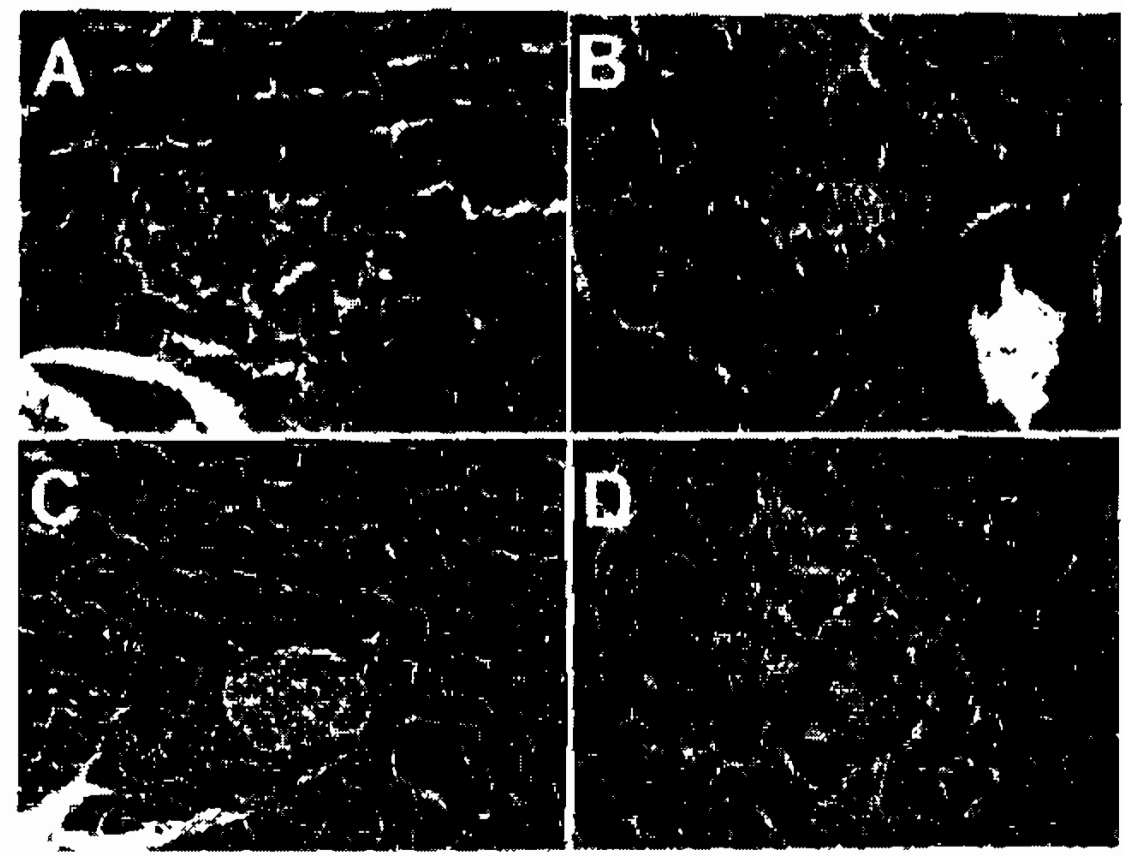

PLfore 2: Photomterouraphs of pancreas show: A. nomal panereas with normal acind (Ac) and 1stets (IL) contalning 3-cells. B: pancreas of diabetic control rats with shrunken tslets. C: pancreas of diabetic rats treated with $50 \mathrm{mg} / \mathrm{kg}$ b. wt of Fenugreek. D: pancreas of diabetse rats treated wt th $500 \mathrm{mg} / \mathrm{kg}$ b. wht of Bitter mcton (A \& $\mathrm{E} \times \mathrm{KO}$. 
Wehaish, F. E.; et al...

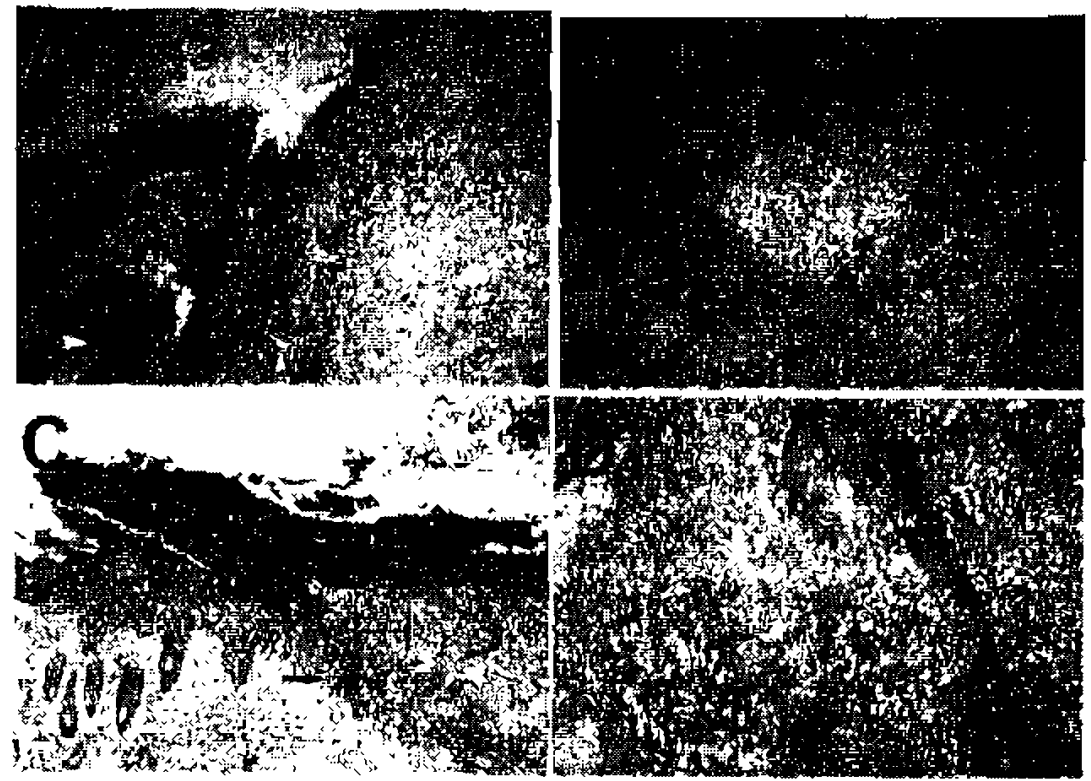

Pigure 3: Photommclograph of skin sections 3 days post wound ereation show $A$ : sken of nomal coritrol rat showing crust (anow head) coventro blood clot represented by nbrin (arrowl and neutrophils (yellow ariow head) and blood platelets besides re-epthelialization (corrugated arrow). B: Skin of dabetic ral showng less inflammatory cells in inllammatory phase. C: Skin of diabetro raf treated with Bitter melon thek crust (arrow bead) gianulation tissue (thin arrow) and re eptthellalizatun (thick arrow). D: Skun of diabeuc rak treated with Fenugreek showing increase number of neutrophlls (corrugated arrow), fibtin (thin arrow) besildes re-eptthellailation (thick arTOW H\&E. x 10.
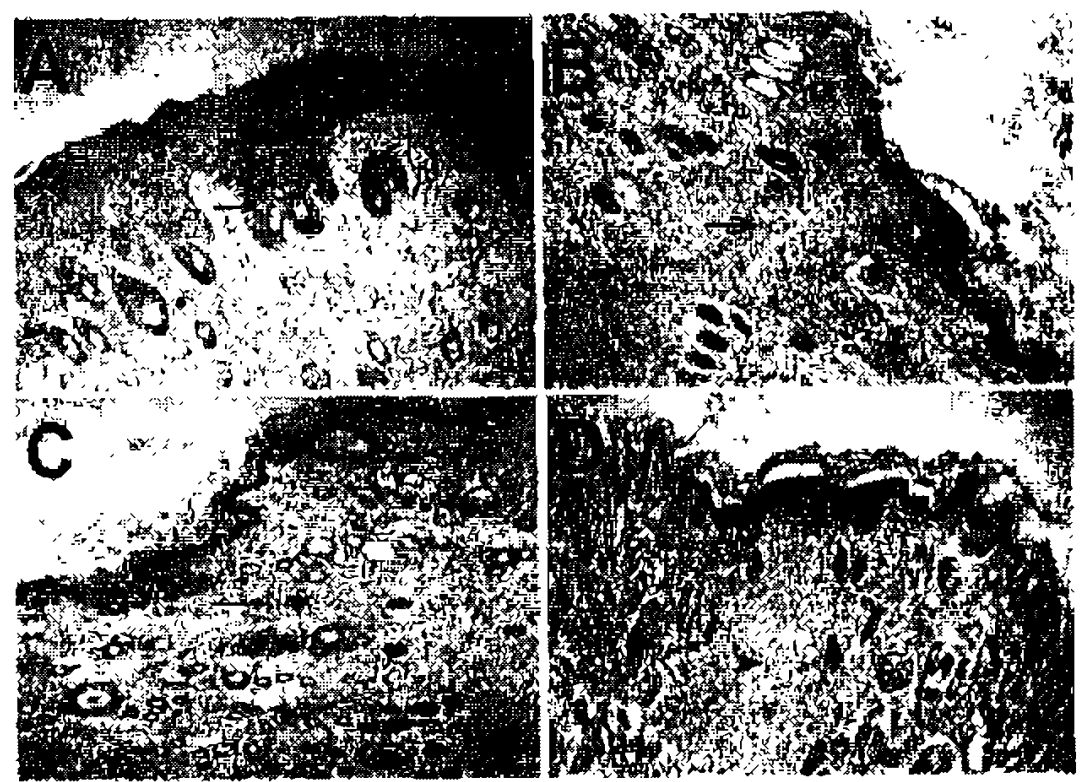

Figure : Pholomicropraply of skin sectlons 3 days post wound creation show A: skin of nomal eontrol rat showing enust (arrow head) covering blood clot represented by fibnin (arrow) and neutrophIts (yellow arrow hoad) and blood platelets besides re-cothefiabizalion (corrugated arnow). B: Skon of drabetic rat showing less inflammatory sells in inflarmonatory phase. C: Skin of dlabettc rat treated with Blcter melon thick crust (arrow head) granulation tlosuc (thilis artow) and re: epithelialization (thick arrow). D: Stan of diabeltc ral treated with Fenugneek showing increase number of nezitrophile (corrugitcd arrow), fibrlar (thin arrow) besides re-epitheliallzation (thick arrow) $H \& E, \times 10$. 


\section{REFERENCES}

Abacl. A; Ogushan, A; Eahraman, 8.; Eryol, N. K.; Unal, B.; Arine, H. and Ergin, A. (2998) : Effect of drabetes mellitus on formation of coronary collateral vessels. Crculaton 99(17): 2239-2242.

Aminl, M. and Parvaresh, E. (2000) : Picvalence of macro- and microvaseular compilcations among patlents with type 2 diabetes in Iran: a systcmatic revew. Dlabetcs Res Clin Fract.:83(1):18-25.

Badra, F. A; Abou-Self, M.; Omama, M. and Ahmed A. F. (2006) : Evaluation of the hypoglycemic effect and mechaniam of action of Balanites aegyptiaca on streptozotocinInduced diabetic rats. First lntemational Symposia about phammacology of natural products and BLACPMA Revista Cubana de Farmacla vol. 40.

Behrendt. D. and Ganz. P. (2002) : Endothellat function, From vascular brology to clentcal appllicatlons. Am J Cardiol 90 (10C): 48.

Boutler, E.; Duron. O. and Kelly, B. M. (1869) : Improved method for the determtnaIJon of blood glutathione. J Lab Clin Mcd. May:61:882.

Bhatla, 6.; Shukla, R.; Vonkata Bradhu, S.: Kaur Gambhlr, J. and Madhava Prabhu, K. (2003) : Antloxldant status. llpjd peroxddation and ritric oxide end products in patients of type 2 dlabetes mellitus with nephropathy. Clin Blochem 36(7): 557-562.

Bud, D. E.; Selby, J. V.; Slewock. P.; Browner, W. B.: Braveman, P. and Bhowstack, J. A (1989) : Lower-extrcmity amputation in people with diabetes. Eptdemtology and prevention. Dlabete Care 12(1): 24-31.

Brausewetter, F.; Jehle, P. M.; Jung, M. F.; Boehm, B. O.; Brueckel, J.; Hombach. V. and Osterhues. H. H. (2001) : Microvas- cular permeability is increased in both types of dtabetes and correlates differentially wth serum ievels of insulun-like growth factor I (IGF-I) and vascular endothelfal growth factor (VEGFy. Horm Metab Res 33(12): 713.720.

Buccolo, $G$ and David, H. (1879) : QuanUtatlve determination of senum trighycerides by use of entymes. clin chem.. 19(5):476-482.

Chaklr, Mri Plante, O, E. avd Maheux, P. (1998) : Reduction of capulary permeabuty in the fructno-Induced hypertensive rat. Am J Hypertens. May: 1 1(5):563-569.

Chaturred, P.; Meorge. A.; Milinganyo, M. and Tripathi, Y. B. (2004) : Effect of Mo mordica charantla on upld profle and oral glucose toleranee In dlabetic rats. Phytother Res 18(11): 954-856.

Cherallier, A (2000) : Encyclopedia of herhal mediclne. New York (NY): Dorling KIndersley Publlshing, Inc. p. 271.

Cobenal, C. J. and eplezirat, F. D. (2003) : Microalbuminurta in insulindependent dtabetes melutur always indlcative or diabedic nephropathy? Pediats Nephrol. 18 (3):309-310.

Colawant, M. and Buxukd, H. (2000): The dual personality of NO. Trends Phamacol Scl $2 L(7): 249-252$.

do Jager, J.; Dekker, J. M.; Kooy, A; Eontense, P. J.; NUpels, G.; Helue, R. J.; Bouter, I. M. and stchouwer, C. D. A. (2008) : Endothelfal dysfunction and lowgrade inflammation explain much of the excess cardsovascular mortallty in Individuals with type 2 diabetes; the Hoom Study. Artertoscler Thromb Vasc Btol 2615): 1086-1093.

Dol, Y.; Kubo, M.; Yonemoto, K.; Ninamilya, $T_{\text {.; }}$ Iwase, M.; Tanleald, Y.; et al.; (2007) : Liver enzymes as a predietor for incldent dlabetes in a Japanese population: the 
Hisayama study. Obesity 15(7): 1841-1850.

Elaner, M.: Guldbakke. B.; Thedge. M.; Munday, R. nad Lenzen, 6. (2000) : Relative importance or transport and alkylation for pancreatic beta-cell toxiclty of streptozotocin. Dlabetologfa. 43(12): ] 528-1539.

Ezokwe, M. O. and Martin, R J. (1980) : The effects of maternal alloxan dlabetes on body composttion, liver enzymes and metabolism and serum metabolites and hormones of retal plgs. Horm Metab Res 12(4): 136m139.

Frledewald, $W$. T.: Levy, $R$. I. and Fredrickwon. D. 8. (1972) : Estimation of the concentration of low-density lipoprotein cholesterol in plasma, without use of the preparatwe ultracentrifuge. Clln Chern. 1972:18 (6):499-502.

Gtustarini, D.; Dalle-Donne, L: Colombo, R.: Mllzand, A. and Rosal, R. (2004) : Adaptation of the Griess reaction for detection of nitute in human plasma. Free Radic Res. 38 (I 1):1235-1240.

Gordon, P. A (2004) : Effects of diabetes on the vascular system: current research evidence and best practice recommendations. $J$ Vasc Nurs. 22(1):2-1)

Guljarro, C.; Kaslake, B. L.; Kím, Y,; O'Donnell, M. P.; Lae. H. B. and Keane, W. F. (1996) : Early glomerular changes in rats with dietary-Induced hypercholesterolemia. Am J KJdncy Dis 26(1): 152-161.

Kamilen, K.: Magmoudi, H.; Carreau, $\mathbf{S .}$ and Elfexl, A (2010): Immunomodulatory, beta-cell, and neuroprotectuve actlons of fenugreek ofl from aljoxan-Induccd dlabetes. Innmunopharmacol Immunotoxicol. $2010 \mathrm{tan}$ 25.

Hannan, J. M. A: All, L.; Rokeya, B.; Khaleque, J.: Akhter, M.: Flatt, P. R. and Abde1-Wahab. Y. H. A. (2007) : Soluble die-
Lary nbre fraction of Triganella Ioenumgraecurn (fenugreek) seed Improves glucose homeostasis In animal models of type 1 and type 2 dlabete by delaydng carbohydrate dgestlon and absorption, and enhancing trisuItn actuon. Br J Nutr.:97(3):514-521,

Hulthen, U. L.; Rumblo, J.; Cooper, M. E. and Johnston, C. I. (1996) : Vascular aibumin permeability and hypertrophy in a rat model cornoining streptozotoctn-finduced diabetes and genetlc hypertension. J Hypertens $13(5): 529-533$.

Inoue, E;; Matsmmoto, M; Miyoshd, $Y$. and Eobayashi, Y. (2008) : Elevated llver enzymex In women with a famlly history of dlabetes. Dlabetes Res Clin Pract 79(3): e4-7.

Iwasald, N.; Ogata, M.; Tomonaga, O.; Eurokd, H.; Kasahara, T.; Yano, N. and Iwamoto, Y. (1998) : Liver and kJdney function In Japanese patlents with maturity-onset diabetes of the young. Dlabetes Care 21(12): 2144-2148.

Jafar, T. H.; Bchmid, C. H. and Levey, A. 8. (2008) : Serurn creatinine as marker of kidney function In South Aslans: a study of reduced GFR in adults in Pakistan. J Am Soc Nephrol 16(5): 1413-1419.

Jeffcoato, w. J.; Price, P. and Handing K. G. (2004) : Internattonal Working Group on Wound Healing and Treatunents for People with Dlabetle Foot Ulcers. Wound healing and treatments for pcople with dlabetic foot ulcer. Duabetes Metab Res Rev; 20: 879-89.

Jombu, I. G.; Zhand, Q.: Falcone, J. C.; Bratcher, A. P.; Rodriguex, W. E. and Tyag, S. C. (200B) : Mechanlsins of endothelfal dysfunction with development of type 1 diabetes mellitus: rolc of insulln and C-peptide. I Cell Blochem 96(6): 1149-1156.

Kalkar, R. Kalra, J.: Montba, S. Y. and 
Prassd. K. (1995) : Upid peroxłation and activity of andiaxddant enzymes in dlabettc rats. Mol Cell Blochen 151(2): 113-119.

Kawanabe. T.; Kawakami, T.; Yatomd, Y.; et al.; (2007) : Sphungosine 1-phosphate accelerates wound healing in dtabethe mice. $J$ Dermatol Sel: 48: 53-60.

Kwong, L. K.; Felngald. K. R; PerteColla, L.: Le, T.; Kurkaw, J. D.; Alberts, A W. and Wheon, D. E. (1801) : Intestinal and hicpatlc cholesterogenesls in hypercholesterolemic dysllpidemla of experimental diabetes in dogs. Dlabetes. 40(12):1630-9.

Lapwhlad, E. A; Sudalkovich, R. J.; Mak-

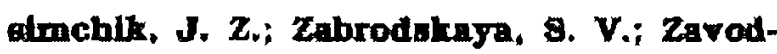
nik, L. B.; et al.; (2000) : Antloxidative enzyme and gutathlone S-trangferase actuvitles In djabetic rats exposed to long-term ASA treatment. LJe Scl 79(19): 1804-1811.

Larsen, $\mathbf{B}$. (1972) : Creatintne asay by a reaction akinetic prinesple. Clin chlm Acta. 41:209-217.

Lawson, S. R.; Cabm, B. H.; Guerin, B.; Neugebauex. W.; Nentel, F.; Battlotinl, B. and Strolo. P. (2008) : Enhanced dermal and retinal vascular permeabulity in streptozotocin-induced type 1 diabetes in Whatar rats: blockade with a sclective bradykinin BI receptor antaganist. Regul Pept 124(1-3): 221224.

Maejlma, K.; Hakano, G.; Himeno, M.; Touda, O.; Maklishi, H.; Ito, T.; Nakagawa, A. at al: (2001) : Increased basal levelg of plasma nitric oxlde in Type 2 dlabetle subJects. Relationship to microvascular compllcations. I Dlabetes Complicattons 15(3): 135143.

Martocchla, A.; Rlalcato, M. G.; Mattioll, C.; Antonelli, M.; Ruco, $\boldsymbol{L}$. and Falaechl, $P$. (2008): Assoclation of diffuse liker glycogeno- ats and mild focal macrovesicular ateatosis in a patient with poorly controlled type 1 diabetes. Intern Emerg Med 3(3): 273.274.

Monind, 8.; Leobint, C.; Odd, G.; Rdceh, C.; Otmonell, P.; Fullucen, B.; ot al.; (2007); increased glomerular cell (podocyte) apoptosts in rats wth streptozotocin-induced diahetes melitus: role in the development of dlabetic glomenular discase. Dlabetologia 50 (12): $2591-2599$.

Mont. D.; Hoyt J., Gibley R. E. and Preat B. H. J. (1988): Parenchymal cytoktne expression precedem clintcally observed ischemia in dorsal flaps in the rat, Plast. Reconstr. Surg. 98 (5) (1996) 856-861.

Nadas, J.: Putz, Z.; Fovenyi, J.; Gual, Z.; Gylmeal. A.; Fudverd, T.; Hosszufalush, R.; ot al.: (2000) : Candiovascular Hok factors characteristic for the metabolic syndrome in aduit patlents with type I dlabetes. Exp Clin Endocrinol Dlabetes. 117(3):107-112.

Nalto, H. K. (1884) : High-denglty lipoprotein (HDL) cholesterol Kaplan. A et al., ciln chem. The co v. Mosby co. st louls. Toronto. Princeton 1207-1213.

Narajlexu, M.; Coones, M. J.: Tu, A H.; Chang, E. Y.; Cao, J.; Ando, A.; An, G. J.; Mella, M. and do Juan, E. Jr. (2001) : Normalkation of retinal vascular permeability in expertmental dtabetes wth ontstetn. Invest Ophthalmol VIs Scd 42(9): 21 10-2114.

Nernurkar, P. Y.; Lee, Y. E.; Motoeve, Mr; Adell, $K$. and Nerurkar, V. R. (2008) : Momordtca charantla (btter melon) reduces plasma apolipoprotein B-100 and increases hepatic tnsulin receptor substrate and phosptroinusitude-3 kinase interactions. Br I Nutr 100(4): $751-759$.

Popato, M. T.; Magrand, M. R.i Eettelhut I. C. and Bronettl. I. L. (1909) : Effect of oral 
vanadyl sulfate treatment on serum enzyries and Iiplds of streptozotocin-diabetic young rats. Mol Cell Bloehern 198(1-2): 157-161.

Perreault, M. and Marette, A (2001) : Targeted discuption of inducible nitric oxdde synthase protects agalnst obesity-linked insuIfn resistance in muscle. Nat Med 7(10): 1138 . 1143 .

Plech. A,; Gao. X.; Bolmadanl, S.; Potter, B. J, Focard, M.; Chillan, W. M. and Zhang. C. (2006) : Tumor necrosis factoralpha Induces endothelial dysfunction In the predtabetic metahollc syndrome, Circ Res 99 (1): 69-77.

Plnzur, M. B.i Slovenkal, M. P.; Trepman, E. and Bhlelds, N. N. (2006) : GuideUnes for diabetic foot care: recornmendations endorsed by the Dlabetes Committee of the American Orthopaedic Foot and Ankle Socicty. Foot Ankle Int 26(1): 113-119.

Powern. A (2008) : Dlabetes mellitus In: Hartison's princlples of Internal medicine IEd Faucl A. New York: Mc Graw Hull.

glu, Z.; Kwon, A H. and Elamiyama, Y. (2006) : Effects of plasma libronectin on the healing of full-thickness skin wounds in streptozotocin-induced diabetic rats. J surg Res: 138: 64-70.

Rettman, 8. and Frankel, 8. (1957) : A colorimetric method for the determination of serum glutamic oxalacetic and glutamle pyravic transaminases. Am $J$ Clin Pathol 1957 $J u): 2 B(1): 56-63$.

Eapin, R.; te Gatudec, V.: Gaser, F.; Plnget, M. and Grucker, D. (2001) : Elecsys insulln assay: free Insulin dcternitration and the absencc of Cross-Reactivity with Insulin Lispro. Clinical Chemlstry. 47:602-605.

Senanayake, G. V.; Maruyama, M.; 8htbuya. K.; Salono, M.; Fukuda, N.; ot al,;
[2004] ; The effects of bitter melon [Momordca charanta) on serum and liver triglycertde lcvels tn rats. J Ethnopharmacol. $91(2-3): 257-$ 62.

Beraralan, G.; Altug. Ex; Kontas, T,; et al: (2007) : Caffele acld phenethyl ester accelerates cutaneous wound heallng in a rat model and decreases oxddative stress. Clin Exp Dermatol: 32: 709-15

Bharma, R. D.; Raghurum, T. C. and Rao. N. 8. (1090) : Eflect of fenugreek seeds on blood glucose and serum liplds in type I diabetes. Eux J Clln Nutr 44(4): $301-306$.

Shetty, A K.; Kumar, G. 8,; 8ambainh. K. and Ealtmath. P. V. (2008) : Effect of bltter gourd (Momordica charanta) on glycaemle status in streptozotocin tnduced diabetic rats. Plant Foods Hum Nutr. 60(3):109-12.

Shih, C. C; Ln, C. H.; Lin, W. L. and Wu, J. B. (2009] : Momordica charantia extrach on trisulin resistance and the skeletal muscle GLuTA protetn In fructose-led rats. I Ethnopharmacol 123(1): 82-90.

Bximudelskd, T. (2001) : The mechanism of alloxan and streptozotocin action th beta cells of rat pancreas, Physlol. Res., 50. 536-546.

Tatsukl, R.; Satoh, K.; Yamamoto, A. Hooht, K. and Ichthura, K. (1897) : Luptd peroxldation in the pancreas and other organs in strcptozotocin diabetic rats. Jpn J Pharmacol. Nov;75(3):267-273.

Teoh, 8, L, Latiff, A A and Das, 8. (2009) : The effect of topical extract of $\mathrm{Mo}$ mordica charantia (bitter gourd) on wound trealling in nondlabetic rats and in rats with diabetes induced by streptozotocin. Cin Exp Dermatol. 34(7):815-22.

Trinder, P. (1869) : Determination of blood glucose using an oxldase-peroxidase systcm with a non carctnogentc chromogen. J 
Cun Pathol 22(2): 158-161.

Vorel, D. (108B) : Simultaneous measurement of piasma volume with dextran and Evans Blue: evidence for Increased vascular permeability in oedema and infection. Clin ScI (Lond) 17(4): 639-646.

vibertl, o. C. (1083) : fncreased capllary perneablity in dlabetes mellstus and its relatonshlp to microvascular anglopathy. Am J Med 75(5B): $81-84$.

VIrdt, J.; Strakamd, S.; Shahanl, S.; Buthar, A. C.; Banavallkar, M. M. and Blyanl, M. K. (2003) : Anthyperglycenle effects of three extracts from Momordica charanta. J
Ethnopharmacol 88(1): 107-111.

Watruabe, C.; Komanuma, Y.; Deftmn, Y. and Satob, H. (1990): The effect of prenatal methylmercury exposure on the CSH level and lipld peroxidation in the fetal brain and placenta of mice. Tohoku J Exp Med 187(2): $121-126$.

Whatby, D. J. and Fergueon, M. W. J. (1801) : Immunohistochemical localization of growth lactorg in retal wound healing, Dev. Biol. 147.

Whaterbourn, C. C. (1096) : Free radlcal toxdcology and antioxddant defence. Clin Exp Phamacol Phystol. Novi22 (11):877-880. 
Wehalsh, F. E.; et al...

الملخص العريسى

بعض الثأثيرات الفسيرلوجية لكلل من الشهام المر والملبة في الجرذان المصابة بمرض البول

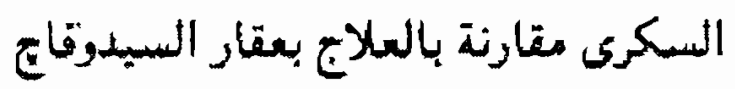

رما مسمد صالل

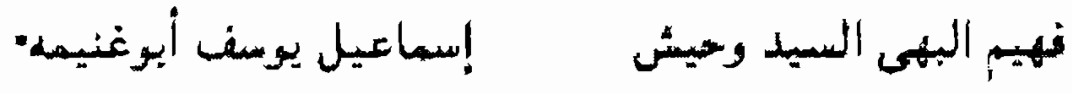

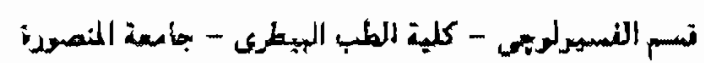

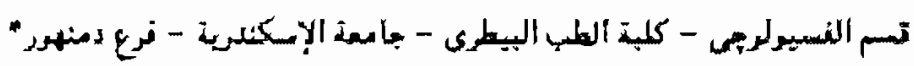

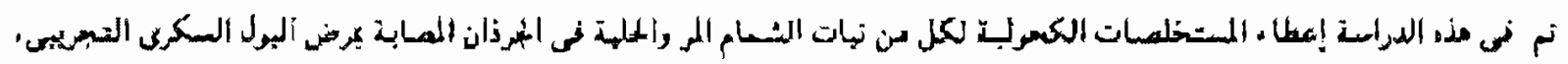

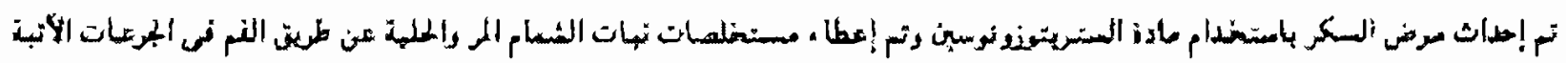

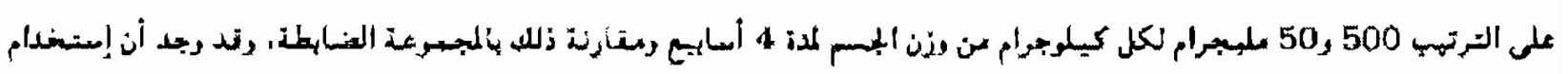

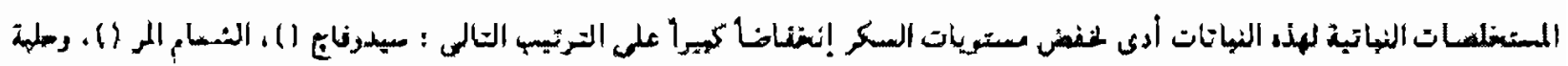

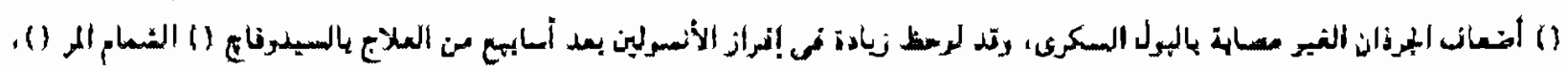

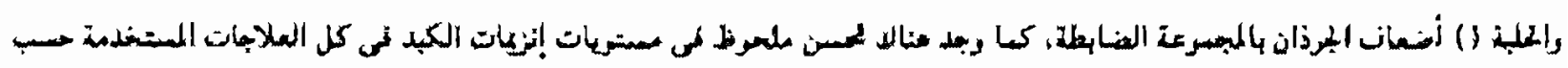

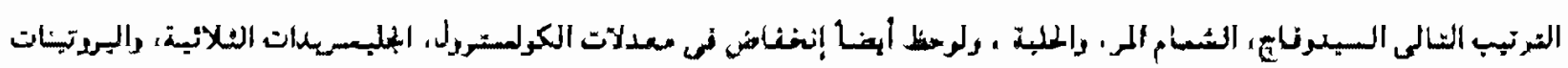

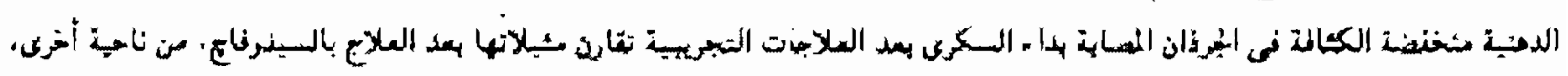

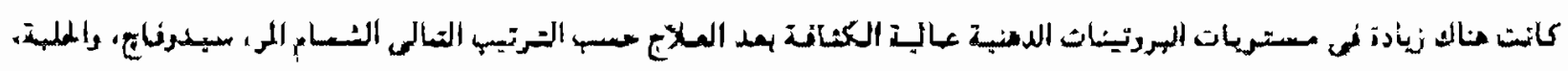

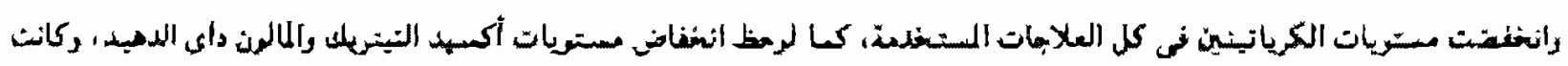

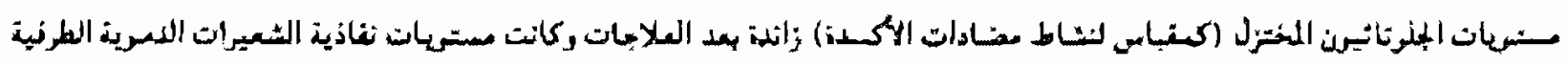

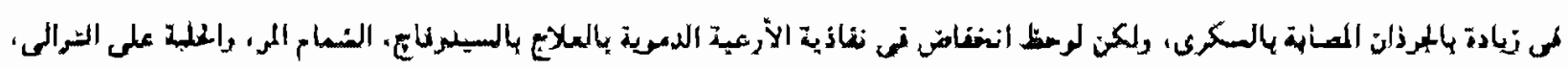

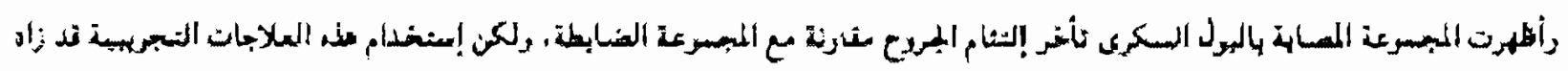

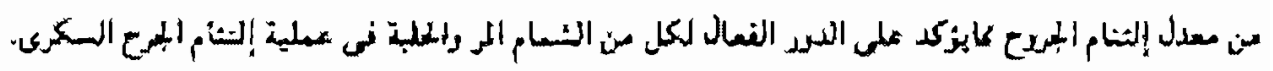

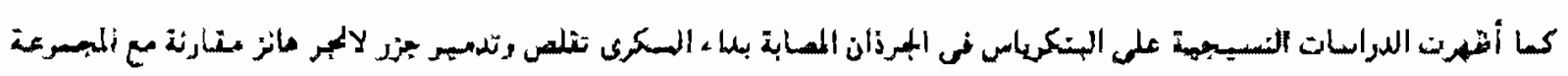

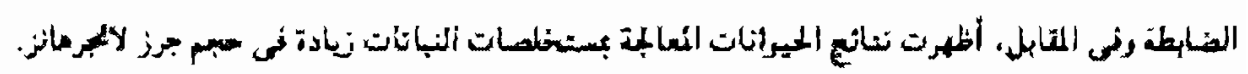

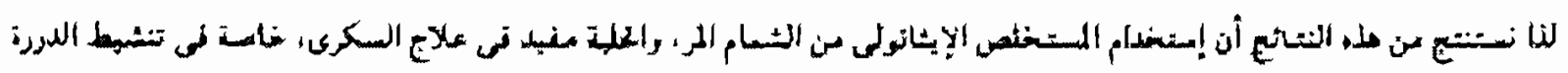

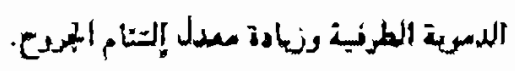

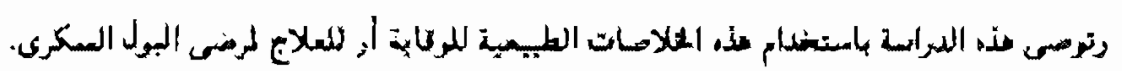

